\title{
AKTIVITAS ANTIBAKTERI MASKER PEEL-OFF EKSTRAK ETIL ASETAT BUNGA MELATI (Jasminum sambac)
}

\author{
Ulfa Wahyu*, Wisnu Cahyo Prabowo, Muhammad Amir Masruhim \\ Laboratorium PenelitiandanPengembangan FARMAKA TROPIS \\ FakultasFarmasiUniversitasMulawarman, Samarinda, Kalimantan Timur \\ *Email: ulpa.wahyu@yahoo.co.id
}

\begin{abstract}
ABSTRAK
Jerawat merupakan masalah kulit wajah yang paling sering dijumpai. Peradangan yang terjadi pada jerawat salah satunya dipicu oleh bakteri Staphylococcus epidermidis. Bunga melati (Jasminum sambac) memiliki kandungan eugenol dan linaloon yang dapat digunakan sebagai antibakteri. Penelitian ini bertujuan untuk mendapatkan masker peel-off yang baik dan memiliki aktivitas antibakteri. Aktivitas antibakteri diuji dengan metode disc diffusion. Data dianalisis dengan ANAVA satu arah serta uji lanjutan Beda Nyata Terkecil (BNT). Hasil uji menunjukkan ekstrak etil asetat bunga melati mampu menghambat pertumbuhan Staphylococcus epidermidis.
\end{abstract}

Kata Kunci : masker peel-off, Jasminum sambac, Antibakteri.

\section{ABSTRACT}

Acne is the most common skin disorder encountered. Inflammation of acne is one of them triggered by the bacterium Staphylococcus epidermidis. Jasmine (Jasminum sambac) contains eugenol and linaloon that can be used as an antibacterial. This study aims to obtain a peel-off mask has an antibacterial activity. Antibacterial activity was tested by disc diffusion method. Data were analyzed by one-way ANOVA and continued by Least Significance Different (LSD) test. The ethyl acetate extract of jasmine was found is able to inhibit the growth of Staphylococcus epidermidis.

Keywords: peel-off mask, Jasminum sambac, Antibacterial

\section{PENDAHULUAN}

Indonesia dianugerahi sumber daya hayati darat dan laut yang beranekaragam serta ribuan etnis suku bangsa yang kaya akan ilmu pengetahuan di bidang pemanfaatan tanaman sebagai sumber obat dan kosmetik. Pemeliharaan kesehatan dan kecantikan tidak terlepas dari produk - produk farmasi, khususnya kosmetika yang sedang diminati adalah kosmetik back to nature. Oleh karena itu penggunaan bahan baku alam untuk kosmetik akan menjadi pilihan utama dimasa depan, karena khasiat dan faktor keamanannya (Rismana, 2014).

Salah satunya masalah kulit wajah yang sering dijumpai adalah jerawat. Jerawat merupakan suatu keadaan dimana pori-pori kulit tersumbat sehingga menimbulkan kantung nanah. Peradangan yang terjadi pada jerawat dapat dipicu oleh bakteri Propionibacterium acne, Staphylococcus epidermidis dan Staphylococcus aureus (Mitsui, 1997).

Secara empiris bunga melati digunakan untuk perawatan kulit dalam bentuk bedak dingin. Pada saat ini penggunaan bedak dingin kurang diminati oleh masyarakat karena 
proses pemakaiannya yang cukup rumit. Sehingga dibutuhkan sediaan yang dapat mempermudah untuk melakukan perawatan kulit, salah satu solusinya adalah sediaan masker peel off.

Masker peel off merupakan salah satu sediaan masker yang praktis dan mudah penggunaannya, terbuat dari bahan karet seperti polivinil alkohol atau damar vinil asetat. Masker peel off biasanya dalam bentuk gel atau pasta yang yang dapat dioleskan ke kulit muka. Setelah pengunaan selama 15 sampai 30 menit akan membentuk lapisan yang dapat diangkat dari permukaan kulit dengan cara dikelupas (Ansel, 1989).

Berdasarkan penelitian yang telah dilakukan oleh Maghfiroh (2014) ekstrak etil asetat dari bunga melati (Jasminum sambac) memiliki daya hambat terhadap pertumbuhan bakteri Staphylococcus aureus dan Shigella flexneri pada konsentrasi 10\%. Selain itu skrinning fitokimia yang dilakukan oleh Rastogi dan Mehrotra (1989) melaporkan bunga melati (Jasminum sambac Ait) memiliki kandungan eugenol, linaloon dan senyawa aktif lainnya pada bunga melati.

Berdasarkan data empiris dan juga hasil penelitian yang telah dilakukan maka dicoba untuk memformulasikan ekstrak etil asetat bunga melati menjadi sediaan masker peel off yang akan digunakan sebagai antibakteri terhadap Staphylococcus epidermidis yang merupakan salah satu bakteri jerawat.

\section{METODE PENELITIAN}

\section{Bahan}

Bahan-bahan yang digunkan dalam penelitian ini adalah Simplisia Bunga Melati (Jasminum sambac), etil asetat, aquadest, tween 80, biakan bakteri Staphylococcus epidermidis, medium nutrient agar, $\mathrm{NaCl}$, polivinil alcohol, polivinil pirolidon, propilenglikol, metil paraben, propil paraben dan etanol

\section{Peralatan}

Alat-alat yang digunkan dalam penelitian ini adalah wadah maserasi, Rotary evaporator, water bath, desikator, timbangan analitik, spatel, sendok tanduk, corong, pipet tetes, pipet ukur, mikropipet, bunsen, kaca arloji, labu ukur, botol vial, paper disc, erlenmeyer, tabung reaksi, cawan perti, ose bulat, autoclave, laminar air flow, Freezer, inkubator, oven, micrometer sekrup, mortir, stamper, gelas kimia, batang pengaduk, magnetic stirer, objek gelas, dan $\mathrm{pH}$ meter

\section{Prosedur}

\section{Penyiapan Sampel}

Bunga Melati yang diperoleh disortasi lalu dicuci hingga bersih dan dikeringkan dengan cara diangin-anginkan hingga diperoleh simplisia bunga melati yang berwarna coklat. Simplisia yang didapatkan kemudian diekstraksi dengan cara maserasi dalam wadah maserasi meggunakan pelarut etil asetat hingga pelarut jernih, hasil maserasi yang diperoleh diuapkan pelarutnya dengan menggunakan rotary evaporator setelah itu disimpan di atas water bath dan di dalam desikator hingga didapatkan ekstrak kering.

\section{Pengujian Aktivitas Antibakteri Ekstrak Etil Asetat Bunga Melati}

\section{Penyiapan Alat dan Pembuatan Medium Nutrient Agar}

Cawan petri dan tabung reaksi dicuci dan dikeringkan, lalu dibungkus menggukan kertas dan untuk tabung reaksi ditutup mulutnya menggunkan kapas terlebih dahulu. Sterilisasi dilakukan dengan menggunakan Autoclave dan dilalukan bersamaan dengan 
sterilisasi medium. Sebelum disterilisasi 5 gram medium nutrient agar dilarutkan dengan aquadest $25 \mathrm{~mL}$ dalam erlenmeyer lalu diaduk di atas hotplate hingga tampak jernih. Setelah itu disterilisasi dengan suhu $121{ }^{\circ} \mathrm{C}$ selama 15 menit. Medium yang sudah steril didinginkan dan disimpan didalam Freezer.

\section{Pembutan Suspensi Mikroba}

Biakan bakteri Staphylococcus epidermidis diinokulasikan kedalam tabung reaksi baru yang berisi medium NA dan diinkubasi dalam suhu $37{ }^{\circ} \mathrm{C}$ selama $1 \times 24$ jam untuk memperoleh biakan baru. Biakan yang didapat kemudian disuspensikan dengan $\mathrm{NaCl} 0,9 \%$ sampai dengan perbandingan 1:40.

\section{Pembutan Larutan Uji}

Ekstrak etil asetat bunga melati ditimbang masing-masing sebanyak 0,$75 ; 0,6 ; 0,5$; 0,35 dan 0,25 gram lalu dilarutkan dengan tween 805 tetes dan aquadest dimasukkan larutan kedalam labu ukur $5 \mathrm{~mL}$ dan ditambahkan aquadest hingga batas dan diperoleh konsentasi 15\%; 12\%; 10\%; $7 \%$ dan 5\%. Selain variasi konsentasi ekstrak dibuat juga larutan kontrol yang melarutkan 5 tetes tween 80 kedalam 5 mL aquadest.

\section{Pengujian aktivitas}

Suspensi bakteri sebanyak $0,02 \mathrm{~mL}$ disebarkan diatas cawan petri hingga merata. Dimasukkan $10 \mathrm{~mL}$ medium NA yang sebelumnya telah dicairkan dan didinginkan didalam cawan petri lalu dihomogenkan. Paper disc direndam didalam larutan uji setelah itu ditempelkan di atas permukaan media agar yang telah mongering. Diinkubasi selama $1 \times 24$ jam di dalam inkubator dengan suhu $37^{\circ} \mathrm{C}$. Diamati dan diukur diameter zona bening yang terbentuk disekitar paper disc menggunkan mikrometer sekrup.

\section{Pembuatan Basis Masker Peel-Off}

Tabel. 1 Formula Basis

\begin{tabular}{|c|c|}
\hline Bahan & Jumlah (g) \\
\hline Polivinil Alkohol & 5 \\
\hline Propilenglikol & 5 \\
\hline Polivinil Pirolidon & 2,5 \\
\hline Metil Paraben & 0,05 \\
\hline Propil Paraben & 0,025 \\
\hline Etanol & 6,25 \\
\hline Aquadest ad & 50 \\
\hline
\end{tabular}

Bahan-bahan yang akan digunakan ditimbang terlebih dahulu. Polivinil Alkohol (PVA) dilarutkan dengan aquadest di atas hotplate dengan magnetic stirrer hingga larut dan tampak jernih. Polivinil pirolidon (PVP) dilarutkan dengan aquadest di dalam gelas kimia hingga larut. PVA dan PVP didiamkan selama 1 hari sebelum dicampurkan di dalam mortir. Metil paraben dan propil paraben dilarutkan ke dalam propilenglikol dan ditambahkan kedalam campuran PVA dan PVP. Campuran ditambahkan dengan etanol dan digerus hingga homogen dan terbentuk massa gel.

\section{Pengujian Organoleptik Basis Masker Peel-Off}

Basis yang telah terbentuk diamati secara organoleptik dengan melihat warna dari basis. Diukur $\mathrm{pH}$ basis dengan menggunakan $\mathrm{pH}$ meter lalu diuji waktu mengeringnya di 
atas objek gelas yang telah disimpan di dalam inkubator selama 1 hari dikatakan mengering apabila masker dapat dikelupas dari objek gelas. Setelah itu Basis dicampurkan dengan konsentrasi efektif dari ekstrak etil asetat bunga melati yang telah diuji sebelumnya dan kembali diamati warna, $\mathrm{pH}$ dan waktu mengeringnya.

\section{HASIL DAN PEMBAHASAN}

Penelitian ini bertujuan untuk mengetahui konsentrasi efektif dari ekstrak etil asetat bunga melati yang memiliki aktivitas antibakteri terhadap Staphylococcus epidermidis dan memformulasikan ekstrak etil asetat bunga melati tersebut menjadi masker peel-off yang digunakan sebagai obat anti jerawat.

Staphylococcus epidermidis merupakan flora normal pada kulit. Infeksi staphylococcus secara lokal dapat menyebabkan jerawat (Irianto, 2006). Staphylococcus epidermidis biasanya ditemukam pada lesi-lesi akne. Berbagai strain Staphylococcus epidermidis dapat menghidrolisis trigliserida menjadi asam lemak bebas dan gliserol, asam lemak bebas tersebut memungkinkan terjadinya lesi komedo (Mitsui, 1997).

Tabel. 2 Hasil Pengujian Antibakteri Ekstrak Etil Asetat Bunga Melati Terhadap bakteri Staphylococcus epidermidis

\begin{tabular}{|c|c|}
\hline Konsentrasi & $\begin{array}{c}\text { Diameter Zona } \\
\text { Bening (mm)* }\end{array}$ \\
\hline $5 \%$ & 6.687 \\
\hline $7 \%$ & 7.238 \\
\hline $10 \%$ & 7.510 \\
\hline $12 \%$ & 8.398 \\
\hline $15 \%$ & 8.191 \\
\hline Total & 38.023 \\
\hline
\end{tabular}

Keterangan: $*=$ Rata-rata dari tiga pengulangan

Salah satu kandungan kimia dari bunga melati adalah eugenol (Rastogi,1989). Menurut Maghfiroh (2010) eugenol merupakan senyawa aktif yang bersifat semipolar sehingga dapat diekstrak dengan pelarut semipolar salah satunya adalah etil asetat. Eugenol bersifat liphopilic yang dapat menembus rantai asam lemak pada lapisan membrane bilayer sehingga dapat mengubah permeabilitas membrane sel. Perubahan permeabilitas membran sel tersebut dapat mengakibatkan penghambatan bahkan kematian sel bakteri. Hal ini disebabkan komponen yang terkandung pada dinding sel bakteri mengalami kerusakan atau kebocoran sel.

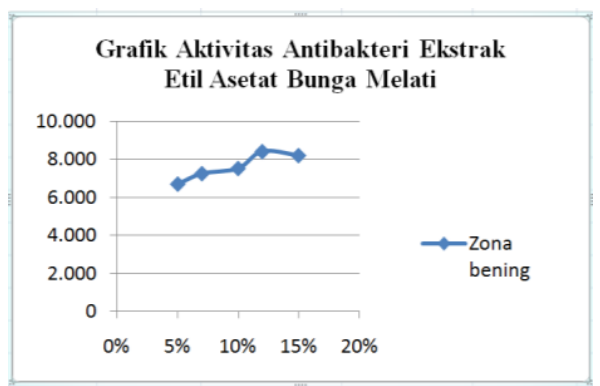

Gambar 1. Grafik Aktivitas Antibakteri 
Berdasarkan grafik pada Gambar 1 diameter zona bening yang dari ekstrak etil asetat bunga melati terhadap bakteri Staphylococcus epidermidis mengalami peningkatan dari konsentrasi $5 \%$ hingga konsentrasi $12 \%$. Pada konsentrasi $15 \%$ zona bening yang dihasilkan lebih kecil. Menurut Dewi (2010) hal ini dapat terjadi karena adanya perbedaan kecepatan difusi senyawa antibakteri pada media agar. Konsentrasi ekstrak yang semakin tinggi artinya ekstrak semakin pekat sehingga sulit berdifusi ke dalam media yang mengandung bakteri. Selain itu juga dapat dikarenakan perbedaan jumlah organism yang diinokulasikan dan kecepatan tumbuh dari bakteri.

Data yang didapat dianalisis menggunakan uji ANOVA satu arah dengan program SPSS 21. Dari hasil analisis diketahui bahwa nilai sig. $<0,05(0,011)$ yang artinya variasi konsentrasi ekstrak etil asetat bunga melati berpengaruh secara signifikan terhadap zona bening yang dihasilkan. Karena adanya pengaruh signifikan dari variasi konsentrasi yang dibuat maka dilakukan uji lanjutan untuk mengetahui konsentrasi terbaik dan konsentrasi efektif dari ekstrak etil asetat bunga melati. Dari hasil uji lanjutan didapatkan hasil bahwa 12\% merupakan konsentrasi terbaik dan 10\% merupakan konsentrasi efektif.

Dikarenakan ekstrak etil asetat yang dihasilkan jumlahnya sedikit maka konsentrasi yang digunakan untuk formulasi adalah konsentrasi efektif. Konsentrasi efektif memiliki aktivitas antibakteri yang tidak berbeda signifikan dengan konsentrasi terbaik. Konsentrasi efektif $(10 \%)$ dapat mengahasilkan zona bening sebesar $7.510 \mathrm{~mm}$. Menurut Davis dan Stouth (1971) diameter zona bening ini dikategorikan antibakteri dengan tingkat kekuatan sedang.

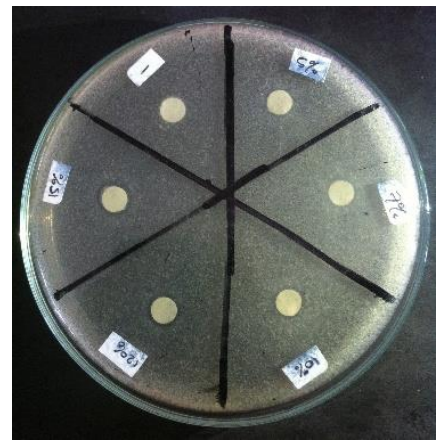

Gambar 2. Hasil Pengujian aktivitas Antibakteri

Basis masker peel-off menggunakan polivinil alkohol sebagai pembentuk gel. Polovinil alkohol adalah polimer sintetis yang larut dalam air berbentuk bubuk granul berwarna putih hingga krem, dan tidak berbau (Rowe, 2009). Polivinil alkohol dapat membentuk lapisan film sehingga lapisan film yang terbentuk dapat diangkat dengan mudah tanpa retak atau robek. Menurut Ansel (1989) polivinil alkohol merupakan bahan pembentuk gel yang cepat kering, memberikan lapisan yang kuat dan elastik, memiliki kontak yang baik dan digunakan untuk pengobatan. Selain menggunakan polivinil alkohol juga digunakan polivinil pirolidon sebagai agen pensuspensi, peningkatkan kelarutan, dan menambah viskositas. PVP sebagai bahan tambahan tidak bersifat toksis dan tidak menginfeksi kulit (Rowe,2009). Ditambahkan juga propilenglikol kedalam basis, digunakan sebagai humektan yang dapat mencegah kehilangan zat pembawa dari sediaan sehingga proses sineresis dapat dicegah, selain itu propilenglikol juga dapat meningkatkan viskositas dari sediaan, dimana sediaan diharapkan cukup kental sehingga mudah dioleskan pada kulit wajah tetapi masih dapat mengalir. Sediaan semi-solid tidak harus steril namun harus memenuhi standari USP test untuk konten mikroba (Ansel, 2011) 
sehingga dibutuhkan pengawet untuk mencegah pertumbuhan mikroba pada sediaan. Pengawet yang sering digunakan dalam sediaan semi solid salah satunya adalah kombinasi propil paraben dan metil paraben. Digunakan dalam bentuk kombinasi karena dapat meningkatkan efeknya terhadap pertumbuhan bakteri dan jamur. Digunakan juga etanol untuk memberikan rasa dingin ketika penggunaan masker dan untuk mempercepat proses pengeringan masker peel-off. Untuk pelarut digunakan aquadest, hal ini dikarenakan polivinil alkohol yang digunakan sebagai bahan pembentuk lapisan film larut dalam aquadest.

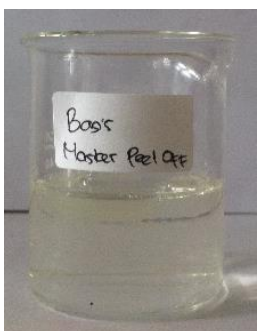

Gambar. 3 Basis Masker

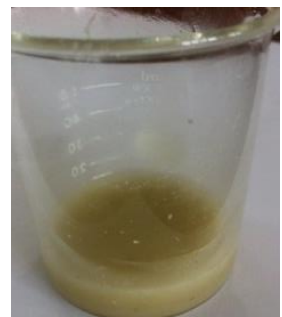

Gambar 4. Basis ditambah ekstrak

Warna basis masker peel-off yang didapatkan berwarna bening dan setelah dicampurakan dengan ekstrak etil asetat bunga melati berwarna hijau. Warna hijau tersebut berasal dari warna ekstrak yang diperoleh.

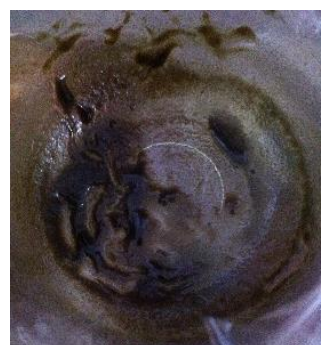

Gambar 5. Ekstrak etil asetat bunga melati

$\mathrm{pH}$ kosmetika diusahakan sama atau sedekat mungkin dengan $\mathrm{pH}$ fisiologis "mantel asam" kulit, yaitu antara 4,5 - 6,5. Kosmetika demikian disebut kosmetika dengan " $p H$ balanced". Adapun $\mathrm{pH}$ dari basis Masker Peel-off adalah 5,58 dan setelah ditambahkan dengan ekstrak etil asetat Bunga Melati $\mathrm{pH}$ menjadi 5,55. $\mathrm{pH}$ tersebut sudah sesuai dengan $\mathrm{pH}$ yang diinginkan.

Waktu mengering sangat diperlukan sebagai prasyarat untuk penerimaan masker peel off. Pengujian kecepatan waktu mengering masker peel-off dilakukan dengan cara mengamati waktu yang diperlukan sediaan hingga mengering, yaitu saat mulai dioleskannya masker peel-off pada objek gelas hingga benar-benar terbentuk lapisan yang kering. Dalam pengujian waktu mengering hasil yang direkomendasikan adalah sekitar 10 sampai 30 menit (Vieira, 2009). Waktu mengering dari basis Masker Peel-off adalah selama 28,10 menit dan waktu mengering untuk basis yang telah ditambahkan dengan ekstrak etil asetat Bunga Melati adalah 27,48 menit. Waktu mengering tersebut sesuai dengan waktu yang direkomendasikan. Waktu mengering dari masker peel-off yang telah ditambahkan dengan ekstrak etil asetat bunga melati lebih cepat dibandingkan basisnya, hal ini dapat dikarenakan kandungan air pada masker peel-off ekstrak etil asetat bunga melati lebih sedikit dibandingkan dengan kandungan air pada basis. Kandungan air yang banyak akan memperlambat penguapan dan pembentukan film pada masker peel-off. 


\section{KESIMPULAN}

Ekstrak etil asetat bunga melati (Jasminum sambac) memiliki aktivitas antibakteri terhadap bakteri Staphylococcus epidermidis dengan konsentrasi terbaik $12 \%$ dan konsentrasi efektif $10 \%$ dan formula masker peel off ekstrak etil asetat bunga melati memiliki warna hijau dengan $\mathrm{pH}$ 5,55 dan waktu mengering 27,48 menit.

\section{DAFTAR PUSTAKA}

1. Rismana,E., Kusumaningrum,S. dan Bunga,O. 2014. Pengujian Aktivitas Antiacne Nanopartikel Kitosan Ekstrak Kulit. Buah Manggis (Garcinia mangostana). Media Litbengkes. Vol 24 (1) 19.

2. Mitsui, T. 1997. New Cosmetic Science. Shiseido Co Ltd: Tokyo.

3. Ansel, H.C. 1989. Pengantar Bentuk Sediaan Farmasi. UI Press: Jakarta.

4. Maghfiroh . 2014. Uji Aktivitas Antibakteri Ekstrak Bunga Melati (Jasminum sambac Ait) Terhadap Pertumbuhan Bakteri Staphylococcus aureus ATCC 25923 dan Shigella flexneri ATCC 12022. Skripsi. Fakultas Sains dan Teknologi Universitas Islam Negeri Sunan Kalijaga Yogyakarta.

5. Rastogi,R.P dan Mehrotra,B.N. 1989. Compendium of Indian Medicinal Plants. CDRI. Lucknow \& NISC. Vol.4

6. Irianto, K., 2006. Mikrobiologi Menguak Dunia Mikroorganisme Jilid I. Penerbit Yrama Widya: Bandung.

7. Dewi, F.K. 2010. Aktivitas Antibakteri Ekstrak Etanol Buah Mengkudu (Morinda citrifolia L) terhadap Bakteri Pembusuk Daging Segar. Skripsi. Fakultas FMIPA Biologi Universitas Sebelas Maret Surakarta

8. Davis, W.W dan Stouth T.R. 1971. Disc Plate Methods of Microbiological Antibiotic Assay. Microbiology. 22 (4).

9. Rowe, R.C., Paul J.S dan Marian, E.Q. 2009. Handbook of Pharmaceutical Excipients $6^{\text {th }}$ Edition. Pharmaceutical Press: Chicago Landon.

10. Ansel, H.C. 2011. Pharmaceutical Dosage Forms and Drug Delivery Systems $9^{\text {th }}$. Lippincott Williams \& Wilkins: Philadelphia.

11. Vieira, R.P. 2009. Physical and Physicochemical Stability Evaluation of Cosmetic Formulations Containing Soybean Extract Fermented by Bifidobacterium animalis. Brazilian Journal of Pharmaceutical Sciences. 45(3). 